\title{
AFTERMATH OF COVID-19 - AN EXPLORATION FOR RESURGENCE - WITH SPECIAL FOCUS ON HEALTHCARE INFRASTRUCTURE IN KERALA
}

\author{
Dr. Rajeeve. L \\ Kerala State Electricity Board Ltd. \\ DOI: 10.46609/IJSSER.2020.v05i07.017 URL: https://doi.org/10.46609/IJSSER.2020.v05i07.017
}

\begin{abstract}
Health and socioeconomic developments are so closely intertwined and it is impossible to achieve one without the other. Persistent and growing socioeconomic gaps result in major discrepancies in the quality of people's health. A set of capabilities and infrastructure are indispensable to prepare and respond to the threat of pandemics. Kerala branded as a model, and it is unique that the standards achieved are comparable with that of the developed countries. A successful primary healthcare infrastructure tested decades back is the myth behind the epic level of the healthcare system. The COVID-19 pandemic is a real eye-opener for all the nations and mankind all over the world. The hospitals and health systems face some causalities and it indicates that a health sector restructuring is absolutely necessary to fight against COVID-19. It warrants greater political will and increased funding for essential health services. This paper explores how we managed the health crisis due to the COVID-19 pandemic so far with our decades tested health care system and explain how the economic and financial crisis can be tied over with innovative strategies, with special emphasis to healthcare infrastructure in Kerala.
\end{abstract}

Keywords: Socio-economic Development, Healthcare Infrastructure, COVID-19 Pandemic, Health System, Kerala.

\section{INTRODUCTION}

The COVID-19 pandemic caused the largest global recession in history and the whole world is grappling with huge financial impact due to it in terms of loss in production, in- come, and employment. The United Nations Development Programme expects a US\$220 billion reduction in revenue in developing countries, and expects COVID-19's economic impact to last for months or even years ${ }^{1}$. Economic upheaval consequent to the pandemic has varied and in- tense impacts 


\section{International Journal of Social Science and Economic Research}

ISSN: $2455-8834$

Volume: 05, Issue: 07 "July 2020"

upon financial and commodity markets. On the demand side, decrease in external demand from trading partners, drop in tourism and tighter domestic financial conditions are the factors that contributed to the dismal performance. On the supply side, services, manufacturing and construction sectors are severely affected by COVID-19. Most of the world famous rating authorities predicted that the world GDP in the coming years will record an abysmally low rate of less than $1 \%$. The Reserve Bank Governor of India has reported that India is going to record a negative growth rate which is the least in the last 40 years history. A study appointed by the Government of Kerala has estimated an aggregate loss of ₹35000 crores to the state economy due to the pandemic. The most pertinent question posed at this time is how we can overcome this troublesome situation and far-reaching unprecedented changes in all aspects of society. What is needed now is a fundamental transformation of economic, social and financial systems that will trigger exponential change in strengthening social, economic, health and environmental resilience $^{2}$. Comprehensive structural reforms are required to achieve more inclusive and sustainable growth. At this juncture, the Government should take economic measures to stabilize markets, enhance liquidity and stimulate growth and boost entrepreneurship in the state for creating jobs and wealth.

\section{BACKGROUND}

Infectious diseases remain one of the biggest threat for mankind in terms of life and livelihood. As human interaction across distances has gone up over time, so has the spread of infections ${ }^{3}$. An array of factors, including increasing population, economic globalization, environmental degradation, and ever-increasing human interaction across the globe are changing the dynamics of infectious diseases. Consequently, the frequency of infectious disease threats to global security increased exponentially. Framed as a health problem, building better defenses against the threat of potential pandemics often gets crowded out by more visible and immediate priorities. Robust public health infrastructure and capabilities are the foundation of a resilient health systems and the first line of defense against infectious disease outbreaks that could become pandemics ${ }^{4}$. Thus, we must make high-quality healthcare services affordable and accessible in order to effectively implement health coverage to all.

For limiting the after effects of COVID-19 in the major economic, financial, health care and employment sectors a concerted effort of government, non-government and social intervention is required. The first objective of every government should be to protect lives, and that means averting the collapse of the health care system. The next priority should be given to ensure that the work force remains employed. The governments should channel financial support to public and private institutions that support vulnerable citizen groups. MSMEs should be safeguarded against bankruptcy for that policies are needed to support the financial system. Further, fiscal 


\section{International Journal of Social Science and Economic Research}

ISSN: $2455-8834$

Volume: 05, Issue: 07 "July 2020"

packages comparable to the crisis related loss of GSDP will have to be financed by adequate measures.

The significance of resilient healthcare system in combating pandemics: World over, health is a priority goal and a central input into economic development and poverty reduction. Health and socioeconomic developments are so closely intertwined and it is impossible to achieve one without the other. A set of capabilities and infrastructure are indispensable to prepare and respond to the threat of infectious diseases. A public health system without strong primary care capabilities will lack both the "radar screen" to pick up the initial cases of an outbreak and the delivery system to execute an effective response strategy ${ }^{5}$. Public health objectives can only be achieved within a highly-functioning and resilient health care system with effective primary care delivery $^{6}$. For building an effective public health care systems, more than surveillance systems, laboratory networks, clinical capabilities and infrastructure are requires.

An effective public health system that can assure quality requires the collaborative efforts of a complex network of people and organizations in the public and private sectors, as well as an alignment of policy and practice of governmental public health agencies at the national, state, and local levels ${ }^{7}$. Cost, access, and quality of health care delivery are intertwined, cannot be odds with each other. Greater use of health care facilities due to lower costs and shorter distances to travel will only lead to better health outcomes if quality of care is guaranteed. Quality health services make health systems resilient, trustworthy and transparent ${ }^{8}$.

Why we need to invest more in healthcare sector: We need to realize that health is an investment in the future. Persistent and growing socioeconomic gaps result in major discrepancies in the quality of people's health. When we think about investment to drive economic recovery, the focus should be very clear and significant. There are several reasons to focus on healthcare system which needs to operate with potency to fight against the virus and taking ample measures to contain its spreading. The COVID-19 pandemic is a real eye opener for all the nations and mankind all over the world. As we learn more from the recent days that hospitals and health systems face some causalities and it indicates that a health sector restructuring is absolutely necessary to fight against COVID-19 pandemic. There is an urgent need for greater political will and increased funding for essential health services. It also needs to invest in research and development of new diagnostics, medicines and vaccines to control the pandemic.

Health Care System in Kerala: Kerala has a long tradition in organized health care. The foundation had already been laid for a sound health care system, incorporated both western and traditional medicine that was accessible to all citizens much before the state formation. Ayurveda, the indigenous system of medicine has been in practice in the land from centuries back. When the 


\section{International Journal of Social Science and Economic Research}

ISSN: $2455-8834$

Volume: 05, Issue: 07 "July 2020"

British colonized the region they brought the modern medical system with them. The concept of primary health care was also started in the region and established mission hospitals in re- mote areas under the aegis of Missionaries. Thereafter, there was remarkable growth and expansion of government health services. From 1961 to 1986, the state greatly expanded its public health facilities. The total number of beds in government hospitals in the modern medical sector increased from around 13000 in 1960-61, to 29000 in 1980-81, 46800 in 2000-01 and to 56793 in 2018-19. The bed population ratio in Kerala is 880 and the average doctor bed ratio is 6.9, probably the highest ratios in the developing world. There are around 1.5 institutions per $10 \mathrm{~km}^{2}$ in the modern medical sector. Moreover, the easy accessibility and coverage of medical care facilities has played a dominant role in shaping the health status of Kerala ${ }^{9}$. The strength of the state is that there are well equipped modern hospitals in all the panchayaths with sufficient doctors, nurses, paramedical staff and health workers. As the investment in health infrastructure has been a consistent policy of all elected governments in Kerala the budget allocation for health was considerable. The tradition of government support for health development, decades back from the Princely rule, has been a catalyst for the advancement of health care in the state.

What makes Kerala to brand as an epic in health care sector: Now the countries all over the world are watching curiously how Kerala has been flattening the curve through high levels of contact tracing and social assistance. Kerala is generally known as one of the most equitable health system in India. Kerala's remarkable achievements in health care were to a large extend based on its vast network of public health institutions which enabled her to earn the fame of "Kerala Model of Health" worth emulating even by advanced countries. The hall mark of this model was the low cost of health care, universal accessibility and availability to the poor sections of the society ${ }^{10}$. Even though the role of the health care sector is significant, the health development in the state is generally attributed to other factors such as the literacy, infrastructure developments, political awareness and social movements. The social and individual health consciousness and awareness owing to high literacy, especially female literacy, contributed much in achieving the high health care standards in the state.

A successful primary health care infrastructure tested decades back is the myth behind the epic level of health care system in Kerala. The other reasons contributed for the better health status of Kerala lies in the fact that state have given equal importance to preventive and primitive measures like sanitation, hygiene, immunization programmes, infant and ante-natal care, health education, etc. as to curative medicine ${ }^{11}$. The disease surveillance system has been functioning extremely well in Kerala, with a robust mechanism for early recognition of any communicable disease of epidemic potential, with speedy response to control and prevent its spread. This aspect has been proved once again when Nipah virus disease outbreak in the State which started in May 2018 and wield appreciation from various experts in the field of communicable disease surveil- 


\section{International Journal of Social Science and Economic Research}

ISSN: $2455-8834$

Volume: 05, Issue: 07 "July 2020"

lance and control, including GoI and World health Organization. With that experience we could act suddenly to respond with the WHO-recommended plan of contact tracing, isolation, and surveillance. The plan relied on consulting patients, mapping their movements to see who they'd interacted with, and isolating anyone in the chain with symptoms ${ }^{12}$. The health department could lead the work in co-ordination with other departments at all levels and the primary response of the health system enabled the state on limiting the morbidity and mortality ${ }^{13}$. The well-established three-tier Panchayath Raj system, the well organized and educated police force, the well knitted network of ASHA workers and Kudumbasree workers are the specialty of the state also played a very important an role in battling against the pandemic. Even though the team work together with our basic infrastructure made a success story in the first and second stages of the outbreak the third stage is totally different which needs much infrastructure, resource and concerted effort to control the pandemic. In fact, our system is adequate to manage a few thousands of patients but it could not afford the turnout is more than that. If such an outbreak occurs in the state that will weaken the system which is already exhausted and the calamity due to that will be severe.

\section{RECOMMENDATION}

Even though tremendous development had taken place in the health sector, the quality of treatment, especially in the rural areas, needs much improvement. The basic medical services are increasingly becoming expensive and the system is turning indifferent towards the poor and deprived section of the society ${ }^{14}$. The COVID-19 underscores that more attention is warranted in the health care sector and that highlights the requirements of renovation of infra- structure. The state must take a step to revamp the health care system in such a way to meet the needs of the people. For that we need large investment initiatives in the health sector in order to develop Kerala as a centre of medical excellence. The policymakers should consider both short- and long-term measures in responding to the COVID-19 crisis that support both customers and utilities. While quick and decisive action is necessary under the circumstances, that action should fit into a broad framework with the dual goal of protecting customers and keeping utilities financially and operationally stable ${ }^{15}$.

For that:

1. Strengthen public health infrastructure and capabilities: The crisis provides ample opportunities to the health systems and individual hospitals to take actions that improve the strength of the overall health care system. Plans to reinforce public health infrastructure and capabilities need combined strategic initiatives. The state government has to take all positive steps to improve affordability, accessibility and quality of health care 


\section{International Journal of Social Science and Economic Research}

ISSN: $2455-8834$

Volume: 05, Issue: 07 "July 2020"

service and must ensure basic health care to the poor and the marginalized. The Government should work to evolve a mechanism for real-time detection and response systems, giving emphasis on timely prevention, early detection, and effective response.

2. Scale up financial resources: Funding of public health services needs substantial increases for the improvement and maintenance of core capacities. The State must ensure that sufficient funding for public health systems is incorporated in budgets. In the Kerala Budget 2020-21 there was nothing to cheer for public health sector; the allocation was only ₹1530 crores including the national health mission and medical education service. As it is a very negligible amount, only $0.17 \%$ of our GSDP, the government should increase the health budget to at least $0.5 \%$ of the GSDP. The issuing of 'Health Infrastructure Bonds', guaranteed by the government, may be pursued for creating health care infrastructure in the state. Municipal bonds on the other hand, offer a way of helping local governments, particularly urban governments to finance critical infrastructure with domestic private capital, rather than sovereign borrowing by national governments. These bonds are usually exempted from taxes ${ }^{16}$.

3. Building partnerships: The increased spending on infrastructure will give a multiplier effect in the growth trajectory of the state and rejuvenate the aggregate demand in the economy and mitigate the impact of Corona Virus. All the governments give much more priority to their health care systems through higher allocation and better utilization of resources in order to improve the quality of health care. But the public sector investment alone cannot build up the healthcare infrastructure to meet the demand of the hour. To achieve the goal of "health for all" for the state is still a distant dream. Given the complex nature of health systems and the diversity of needs and expectations from a large heterogeneous population no single agency can satisfactorily address the health needs. Private sector supporting can be availed alongside government funds to extend response efforts and meet rapidly emerging needs. To deliver an adequate response during outbreaks, it needs to build and maintain partnerships with other public, private, and nonprofit sectors and work closely with communities and community-based organizations. Public-private collaboration and intergovernmental coordination are critically important in creating effective outbreak response. These groups have immense breadth and depth of experience addressing public health issues and can ensure alignment with the health care ecosystem ${ }^{17}$. For improved delivery of demand driven healthcare services Public Private Partnership (PPP) and Public Private People's Partnership (PPPP) can be promoted. Hence governments, corporate sectors, NGOs and other sectors of societies have to enter into mutually beneficial partnership to serve the health needs of the poor and the lower income groups. Finance can be sourced from varied sectors and 
International Journal of Social Science and Economic Research

ISSN: $2455-8834$

Volume: 05, Issue: 07 "July 2020"

repayment of the same can be met from the revenue generated through fees levied for services like diagnostic fees, facility fees, room rents etc. provided to higher income groups.

4. Improve health information system: Effective surveillance is critical in containing infectious disease outbreaks. Today new technologies like big data analytics, artificial intelligence are playing a vital role in transforming the health care sector. Research data become the most important asset now and storing of vital data and management of information system are very essential for the health professionals to perform their functions more effectively. The data storing and analysis must be carried out by governmental agencies with sufficient credentials ensuring security and precision. The information sys- tem should be envisaged as a multilevel network system and that should be integrated with the disease surveillance system at every level of the health care system to ensure that information reaches decision makers quickly.

5. Regulations over the private sector: The public and private sector would effectively cooperate and complement each other to conquer the pandemic. But private health care sector should be properly regulated to ensure minimum standards, quality and affordability. The regulatory authority should have the powers to set up standards for hospitals and health centres at various levels and audit the actions of private hospitals. This regulatory body must be composed of medical and legal experts, along with representatives from the Government.

6. Enhancing the role of academic and research institutions: The academic and research institutions can play a vital role to improve the effectiveness and efficiency in the public health sectors. The institutions should facilitate updating the technical knowledge of the existing medical professionals through continuing medical/health education. They can help indigenize global technologies and make them available at a very low $\operatorname{cost}^{18}$.

7. Public health workforce: A high priority should be given to skilled, motivated, and well-supported health workforce to sustain an effective and responsive public health sys- tem. No health system can achieve its goals without this. Therefore, the state should oblige to develop and implement a workforce-strengthening strategy and plan that includes training programs for health professionals. A strong and robust cadre of health workers, like Asha workers, should be raised so that they can reach to every panchayat and household.

8. Increase laboratory network and testing: There is an apprehension among the experts 
International Journal of Social Science and Economic Research

ISSN: $2455-8834$

Volume: 05, Issue: 07 "July 2020"

that Kerala is not doing adequate number of tests and several cases remain undetected. If Kerala tests more there will be the possibility of more positive cases but can control community spreading. It necessitates wide laboratory network which is a key component of a highly-functioning public health system. Such a network needs to be able to systematically identify, collect, and transport specimens to laboratories with adequate equipment and personnel to carry out reliable testing. Technological innovation promises more cost-effective and rapid diagnostics. However, it also requires trained biomedical engineers, a scarce resource, that is critical to the functioning and integrity of a high quality laboratory network.

9. Engaging and communicating with communities: Effective response to a potential pandemic requires skills beyond the health arena. Therefore, governments should engage with key players in non-health sectors, such as civil society organizations to prevent the transmission of the disease as they are working closely with the communities. These individuals and organizations at the regional and local levels recognize the need to work with a range of influential people in many roles and understand the importance of developing trusting relationships.

10. Promote social health insurance: The previous UDF government introduced Karunya Arogya Suraksha Padhati, a benevolent health coverage scheme, for the socially depressed communities which offer an annual health insurance cover of ₹5 lakh to 47 lakh families. The LDF government in its budget-20-21 declared it stopped but forced to resume due public roar. The insurance scheme announced for the government employees remain in red tapes even after yearlong discussions. Government should encourage social health insurance which are low cost subsidized insurance packages specifically developed for the poor and lower socioeconomic classes. The premium should be bearable to the lower middle class and it should be exempted for the deprived classes.

11. Telemedicine should become a norm: Preventive healthcare should be on a top priority of the government as it has immense benefits. The government should also come out with policies and guidelines to promote telemedicine.

12. Health care at door step: Healthcare services should be provided at the doorstep to the extent possible. Doctors and professionals should reach the grassroots level.

Health is a fundamental human right and a basic need to attain better quality of life. Health service should be available to all citizens irrespective of their ability to pay for. Investing in the health system not only save lives, it is also a crucial investment in the wider economy. This is because ill-health weakens productivity, hampers job prospects and adversely affects human 


\section{International Journal of Social Science and Economic Research}

ISSN: $2455-8834$

Volume: 05, Issue: 07 "July 2020"

capital development. There has been a strong political and historical commitment to treat health as a social goal either through legislation or mandating and prioritizing expenditure on health ${ }^{19}$. Around the globe, hospitals and health systems are making heroic efforts to meet the challenges of COVID-19. Strengthening public health systems will not only prevent a future outbreak from spinning out of control, but also support other critical efforts to combat global health threats.

\section{Other sectors which need special attention}

MSME and hospitality sector: It is absolutely certain that the MSMEs and hospitality sector which form the back born of the economy worldwide will be the worst hit sectors due to the lock down consequent to the COVID-19. Kerala has to suffer the worst effect of the lock down as it is a consumer state that depending other states for its daily consumption. It is estimated that the state would suffer an economic loss of ₹80000 crores due the disastrous pandemic. Cash transfers, tax holidays, working capital support could be provided as catalyst in boosting the MSMEs. For increasing the working capital of the firms which suffers liquidity problems provide them a term-loan with a provision of 3 years repayment period is very crucial at this juncture. Deferment of EMIs of the term-loans for 6 months with interest subvention @ 3\% in loans to MSMEs, restaurants and other badly affected industries are other supportive measures to tide over the liquidity crisis at this hard time. As raw materials are the important inputs of the industry the government should reduce the tax and duties on basic raw materials by at least 5 percent- age points. For electricity and other utility bills certain reduction in fixed charges should be given on prompt payments. The consumption expenditure of the government should also be enhanced to revive the demand scenario in the economy, even if there is increase in the fiscal deficit.

Agriculture Sector: One another important sector which needs urgent attention is agriculture. Huge damage has already been occurred in terms of loss in the fisheries and food processing sector. We have to extend our agriculture production to the maximum in order to cop up the shortage of consumables for that now we resorted other states. Farming has to be increased in war footing level in all the Panchayaths and encourage roof top cultivation of vegetables. Cultivation of tuber crops like tapioca, sweet potato, ginger, turmeric, yam and cultivations like paddy, plantain and fruits has to be promoted domestically. All the barren land must be used for food production to the maximum extent. We have to return back to the previous era of producing milk, meat, egg and vegetables for our domestic use and livelihood.

Tourism Sector: Our Tourism sector was about to stand aright after Nipa Virus outbreak and two severe floods but now it is one of the worst hit sectors due to the COVID-19. As this sector contributes $12 \%$ of the GSDP it will result some serious repercussions in the state. In tourism sector, Kerala had attracted around 1.96 crore domestic and foreign visitors and generated a sum 


\section{International Journal of Social Science and Economic Research}

ISSN: $2455-8834$

Volume: 05, Issue: 07 "July 2020"

of $₹ 45,000$ crore in 2019 , registering a healthy growth of 17.2 per cent. But now the Confederation of Kerala Tourism Industry (CKTI) estimates that the State's tourism industry will witness a revenue loss to the tune of ₹20,000 crore this year due to the impact of COVID-19. An additional promotional budget should be provided by the government to promote domestic tourism as there is a less possibility of revival in arrival of international tourists in the coming times.

Taxes such as corporate and municipal taxes, and also license fees may be deferred for six months. Banks and financial institutions should extend a moratorium for the next 12 months on all interest and principal to be paid on loans availed by tourism entrepreneurs through a special directive. With regard to electricity high tension (HT) users, they may be charged minimum rates and electricity subsidy reinstated for their benefit.

Special package for NRIs: Kerala has been the hub of NRI deposits in the country and the state economy is substantially maintained by the NRI receipts. Remittance from Non-Resident Indians stimulated the economic development of the state by enhancing the quality of life and contributes to a high human development index in terms of education and health, along with the reduction of poverty and unemployment ${ }^{20}$. Due to the COVID-19 impact, at least $10-15 \%$ of the NRIs will return to India and most of them are Keralites. As a result, together with the livelihood problems of NRIs the state could face economic crisis which will last for several months. In this hard time the government should come up with a comprehensive financial package for supporting the NRIs for setting up their livelihood and lead a meaningful life. Government should also think about setting up of companies like Uralunkal Labour Contract Company (ULCC) to utilise the expertise at various levels of the NRI and provide livelihood support.

Enhance capacity for power management in the State: When we build up enough healthcare capacity to take on a pandemic, we also need to build up extra capacity in the power sector to take on the peak load, which could be $30 \%$ to $80 \%$ higher than normal load. It is also required to build up mechanism to avoid power outages when it is used intensively and factor the cost of the unutilised capacity during off-peak hours into the pricing of power. Incentives should be given to households, housing societies, enterprise and industry to gradually switch over to renewable energy.

Need stringent measures to control government expenditure: Kerala is known as consumer states since it produce only $13 \%$ of its consumables and for the rest resorts the other states. Industrial production is comparatively low in the state subsequently; there is low employment generation as industries act as major employment generator. In this circumstance the state ultimately resorts liquor and lottery for revenue generation and further for meeting the revenue gap government finds debt as the alternative option. The main expenditures such as salary, 


\section{International Journal of Social Science and Economic Research}

ISSN: $2455-8834$

Volume: 05, Issue: 07 "July 2020"

pension and interest on debt are mounting every year in an exponential manner. The poor fiscal management leads to unpredictable releases and delayed expenditure. The financial extravaganza and laxity in fiscal prudence also leads to higher fiscal deficit. In this context, the government must be more vigilant to ensure projects are implemented on. Government should also take stringent measures to check the extravaganzas and control the non-plan expenditure due to the obesity of the bureaucratic setup, at a rational level.

Explore the scope of investment from other countries: As China, the origin of the COVID-19 pandemic is being alienating by other countries and planning to divert their investment to other countries. This is a great opportunity to India and Indian entrepreneurs to attract investment from companies that want to move out from China and diversify their base in investment friendly countries. The present opportunity will open up avenues to explore possibilities of tie- up with companies from various countries like US, UK etc. which are operating now in China. As Kerala has bestowed world accolades in managing the Corona pandemic, the state must use this opportunity to attract these entrepreneurs to invest in the state by making investment friendly scenarios which are conducive to attract the investors. We must also take the advantage of the opportunity for the productions of goods to become self-sufficient and can be an exporter of such products.

Need a "COVID Crisis Package" for inclusive growth: Even though the damage caused to the state economy due to the lock down subsequent to COVID-19 cannot be estimated at this time, the governments have to start reforms process to make the economy vibrant and productive to overcome the crisis. Significant reforms are warranted across the sectors such as agriculture, manufacturing and services. Expenditure rationalization measures and efficient use of funds are also need to be examined. The economic revival requires several prerequisites, such as building up of the financial mediation system, for that the banks have to pump money into the market to enhance the demand, but are reluctant to do so. An ample solution for that is to request RBI to issue new corporate bonds to be subscribed by the banks to solve the problem. Large-scale credit guarantees and interest subventions for bank loans to small and medium enterprises are another pre-requisite. Disbursing subsistence allowances to those rendered jobless is another vital task ${ }^{21}$. In this hard time the government should urgently come up with an economic revival package for inclusive growth and resurgence of economy. A fiscal stimulus of at least 5\% of GSDP is needed to mitigate the impact on the economy, trade and industry through various relief measures and benefits. The State government can institute a "COVID Crisis Package" to help companies succumbed to the blow of COVID-19 outbreak for giving benefits to the affected workers, as well as bridge-loans and credit guarantees to shore up businesses' liquidity. 
International Journal of Social Science and Economic Research

ISSN: $2455-8834$

Volume: 05, Issue: 07 "July 2020"

\section{CONCLUSION}

The world is going through a difficult and unprecedented situation due to the COVID-19 pandemic. Chang Yong Rhee, Director of the IMF's Asia and Pacific Department says that "Comprehensive structural reforms are needed to achieve more inclusive and sustain- able medium-term growth. Long-standing and medium-term priorities include infrastructure investments, land, product market, labour, and other reforms, such as increasing female labour force participation and access to finance to create more and better jobs". The public sector's role in the financial system needs to be reduced to raise credit allocation efficiency, he added. At this juncture we should remember the words of John K Rockefeller the American business magnet and philanthropist and the wealthiest American of all time that "I always tried to turn every disaster into an opportunity". Our Prime Minister also remembered the country, "The COVID-19 pandemics taught us some hard realities and the importance of being self-reliant and selfsufficient and not look for solutions from abroad. Our villages, districts and states should be able to provide all the basic needs and, of course, our collective power would help us to move forward". What we have to do at this moment is to infuse money in to the entire worst hit sectors to rejuvenate them immediately to ensure the resurgence of our economy.

\section{REFERENCES}

1. Palumbo, Daniele (28 March 2020), "Coronavirus: A visual guide to the economic impact", BBC News. Archived from the original on 27 March 2020.

2. Phoebe Koundouri, Co-Chair of SDSN Greece, Never Waste a Good Crisis: For a Sustainable Recovery from COVID-19, 01 Apr, 2020.

3. Stefan Kapferer, The importance of investing in health http://weforum.us3.list-manage.com/subscribe?u=79c86265202b9840297f805ad\&id=7361259375.

4. A Framework to Counter Infectious Disease Crises, Commission on a Global Health Risk Framework for the Future; National Academy of Medicine, Secretariat: ISBN 9780-309-39093-4 | DOI: 10.17226/2189.

5. Standley et al., 2015. The Neglected Dimension of Global Security: A Framework to Counter Infectious Disease Crises, Strengthening Public Health as the Foundation of the Health System.

6. The World Health Report: Primary health care "now more than ever." Geneva: WHO; 2008b.

7. https://www.resolve.ngo/docs/phlf developingafinancingsystemtosupportpublichealth636869439688663025.pdf.

8. Valerie Shelly, Susann Roth, Kirthi Ramesh: Healthcare must be Affordable and Accessible, but also High Quality in Community, Governance; originally appeared on the 
International Journal of Social Science and Economic Research

ISSN: $2455-8834$

Volume: 05, Issue: 07 "July 2020"

Asian Development Bank blog, March 30, 2020.

9. V Raman Kutty, Historical analysis of the development of health care facilities in Kerala State, India, Health Policy And Planning; 15(1): 103-109,@) Oxford University Press, 2000.

10. Government of Kerala. Economic Review 2010. Thiruvananthapuram: State Planning Board, 2011. https://www.mei.edu/publications/remittances-kerala-impact-economy

11. Rajan, 1993: shodhganga.inflibnet.ac.in: https://www.google.com/url.

12. Sonia Faleiro, What the world can learn from Kerala about how to fight covid-19, MIT Technology Review, April 13, 2020.

13. Government of Kerala. Economic Review 2019. Thiruvananthapuram: State Planning Board, 2020.

14. Dr.Rajeeve. L, Infrastructure financing and its socioeconomic impact in Kerala, University of Kerala, 2017.

15. Wilkinson Barker Knauer, COVID-19 and Critical Infrastructure: An Agenda for Decisive State Regulatory Action, April 2020.

16. Timothy C. Okech $(\mathrm{PhD})$, Empirical Assessment of the Various Sustainable Financing Mechanisms for Health Care Services in Kenya, International Journal of Academic Research in Economics and Management Sciences, Vol. 1, No. 3 ISSN: 2226-3624, June 2012.

17. Bechara Choucair, Chief Health Officer at Kaiser Permanente, PR Newswire, March 11, 2020.: https://finance.yahoo.com/news/kaiser-permanente-contributes-1-million100000428.html,

18. K.V. Ramani and Dileep Mavalankar, Health system in India: opportunities and challenges for improvements, Indian Institute of Management, Ahmedabad, India. Journal of Health Organization and Management, Vol. 20 No. 6, 2006,pp. 560-572 Emerald Group Publishing Limited,1477-7266.

19. Stefan Kapferer, The importance of investing in health, The World Economic Forum COVID Action Platform, 18 Dec 2015:https://www.weforum.org/agenda/authors/stefankapferer.

20. S. Irudaya Rajan, K.C. Zachariah, Remittances to Kerala: Impact on the Economy, Middle East Institute, February 2010.

21. T.K Arun, Investing in healthcare infrastructure can drive growth, prepare for next pandemic, Economic Times, 15 Apr, 2020 12:04 AM IST, https://economictimes.indiatimes.com/etreporter/author-T20K20 Arun-7911.cms. 